\title{
Managing Metadata for Philatelic Materials
}

Megan Ozeran

\begin{abstract}
Stamp collectors frequently donate their stamps to cultural heritage institutions. As digitization becomes more prevalent for other kinds of materials, it is worth exploring how cultural heritage institutions are digitizing their philatelic materials. This paper begins with a review of the literature about the purpose of metadata, current metadata standards, and metadata that are relevant to philatelists. The paper then examines the digital philatelic collections of four large cultural heritage institutions, discussing the metadata standards and elements employed by these institutions. The paper concludes with a recommendation to create international standards that describe metadata management explicitly for philatelic materials.
\end{abstract}

\section{INTRODUCTION}

Postage stamps have existed since Great Britain introduced them in 1840 as a way to prepay postage. Historian and professor Winthrop Boggs (1955) points out that postage stamps have been collected by individuals since 1841, just a few months after the first stamps were issued (5). To describe this collection and research, the term philately was coined by a French stamp collector, Georges Herpin, who "combined two Greek words philos (friend, amateur) and atelia (free, exempt from any charge or tax, franked)" (Boggs 1955, 7). Thus postage stamps and related materials, such as the envelopes to which they have been affixed, are considered philatelic materials.

In the United States, numerous societies have formed around philately, such as the American Philatelic Society, the Postal History Society, the Precancel Stamp Society, and the Sacramento Philatelic Society (in northern California). The definitive United States authority on stamps and stamp collecting for nearly 150 years has been the Scott Postage Stamp Catalogue, which was first created by John Walter Scott in 1867 (Boggs 1955, 6). The Scott Catalogue "lists nearly all the postage stamps issued by every country of the world” (American Philatelic Society 2016). Philately is a massively popular hobby, and cultural heritage institutions have amassed large collections of postage stamps through collectors' donations.

In this paper, I will examine how cultural heritage institutions apply metadata to postage stamps in their digital collections. Libraries, archives, and museums have obtained specialized collections of stamps over the decades, and they have used various ways to describe these collections, such as through creating finding aids. Only recently have institutions begun to digitize their stamp collections and make the collections available for online review, as digitization in general has become more common in cultural heritage institutions.

Megan Ozeran (megan.ozeran@gmail.com), a recent MLIS degree graduate from San Jose State University School of Information, is winner of the 2017 LITA/Ex Libris Student Writing Award. 


\section{PROBLEM STATEMENT}

Textual materials have received much attention in regards to digitization, including the creation and implementation of metadata standards and schemas. Philatelic materials are not like textual materials, and are not even like photographic materials, which have also received some digitization attention. In fact, there is very little literature that currently exists describing how metadata is or should be applied to philatelic materials, even though digital collections of these materials already exist. Therefore, the goal of this paper is to examine exactly how metadata is applied to digital collections of philatelic materials. Several related questions drove the research about this topic: As institutions digitize stamp collections, what metadata schema(s) are they using to do so? Are current metadata standards and schemas appropriate for these collections, or have institutions created localized versions? What metadata elements are most crucial in describing philatelic materials to enhance access in a digital collection?

\section{LITERATURE REVIEW}

While there is abundant literature regarding the use of metadata for library, archives, and museum collections, there is a dearth of literature that specifically discusses the use of metadata for philatelic materials. Indeed, there is no literature at all that analyzes best practices for philatelic metadata, despite the fact that several large institutions have already created digital stamp collections. Even among the many metadata standards that have been created, very few specify metadata guidelines for philatelic collections. It is clear that philatelic collections have not been highlighted in discussions over the last few decades about digitization, so best practices must be inferred based on the more general discussions that have taken place.

\section{The Purpose and Quality of Metadata}

When considering why metadata is important to digital collections (of any type), it is crucial to remember, as David Bade (2008) puts it, "Users of the library do not need bibliographic records at all... What they want is to find what they are looking for" (125). In other words, the descriptive metadata in a digital record is important only to the extent that it facilitates the discovery of materials that are useful to a researcher. As Arms and Arms (2004) point out, "Most searching and browsing is done by the end users themselves. Information discovery services can no longer assume that users are trained in the nuances of cataloging standards and complex search syntaxes" (236). Echoing these sentiments, Chan and Zeng (2006) write, "Users should not have to know or understand the methods used to describe and represent the contents of the digital collection" (under "Introduction"). When creating digital records, then, institutions need to consider how the creation, display, and organization of metadata (especially within the search system) make it easier or more difficult for those end users to effectively search the digital collection.

How effective metadata is in facilitating user research is ultimately dependent upon the quality of that metadata. Bade (2007) notes that the information systems are essentially a way for an institution to communicate with researchers, and that this communication is only effective if metadata creators understand what the end users are looking for in the content and style of 
communication (3-4). Thus, in somewhat circular fashion, metadata quality is dependent upon understanding how best to communicate with end users. To help define discussions of metadata quality, Bruce and Hillmann (2004) suggest seven factors to consider: "completeness, accuracy, provenance, conformance to expectations, logical consistency and coherence, timeliness, and accessibility" (243). Deciding how to prioritize one or several factors over the others will depend on the resources and goals of the institution, as well as the ultimate needs of the end users.

\section{The State of Standards}

Standards are created by various organizations to define the rules for applying metadata to certain materials in certain settings. Standards generally describe a metadata schema, "a formal structure designed to identify the knowledge structure of a given discipline and to link that structure to the information of the discipline through the creation of an information system that will assist the identification, discovery and use of information within that discipline" (CC:DA 2000, under "Charge \#3"). Essentially, a metadata schema standard demonstrates how best to organize and identify materials to enhance discovery and use of those materials. Such standards are helpful to catalogers and digitizers because they define rules for how to include content, how represent content, and/or what the allowable content values are (Chan and Zeng 2006, under "Metadata Schema").

Unfortunately, very few current metadata standards even mention philatelic materials, despite their unique nature. The only standard that appears to do so with any real purpose is the Canadian Rules for Archival Description (RAD), created by the Bureau of Canadian Archivists in 1990, and revised in 2008. Thirteen chapters comprise the first part of the RAD, and these chapters describe the standards for a variety of media. Philatelic materials are given their own focus in chapter 12, which discusses general rules for philatelic description as well as specifics for each of nine areas of description: title and statement of responsibility, edition, issue data, dates of creation and publication, physical description, publisher's series, archival description, note, and standard number. The RAD therefore provides a decent set of guidelines for describing philatelic materials.

The Encoded Archival Description Tag Library created by the Society of American Archivists (EAD3, updated in 2015) mentions philatelic materials only in passing. There is no specific section discussing how to properly apply descriptive metadata to philatelic materials. The single mention of such materials in the entire EAD3 documentation is in the discussion of the <materialspec $>$ tag, where it is noted that "jurisdictional and denominational data for philatelic records" (257) may be recorded.

Other standards don't appear to mention philatelic materials at all, so implementers of those standards must extrapolate based on the general information provided. For example, Describing Archives: A Content Standard (DACS), also published by the Society of American Archivists (2013), does not discuss philatelic materials in any way. It does note, "Different media of course require different rules to describe their particular characteristics..." (xvii), but the recommendations for specific content standards for different media listed in Appendix B still leave out philately (141142). Institutions using DACS for philatelic materials need to determine how to localize the standard. Although MARC similarly does not include specific guidelines for philatelic materials, Peter Roberts (2007) suggests ways to effectively use it for cataloging philatelic materials. For 
instance, in the MARC 655 field he suggests using the Getty Art and Architecture Thesaurus terms to describe the form of the materials and the Library of Congress Subject Headings to describe the subjects (genres) of the materials (86-87). In similar ways, most standards could potentially be applied to philatelic materials if an institution were to provide additional local rules for how to best implement the standard.

\section{The Metadata that Philatelists Want}

There are actually a good number of resources for determining what metadata is important to philatelic researchers. Boggs (1955) suggests that a philatelist may want to "study the methods of production; the origin, selection, and the subject matter of designs; their relation to the social, political and economic history of the country of issue; the history of the postal service which issued them" (1-2). These few initial research suggestions can provide some insight into what metadata elements would be most useful in a digital record. David Straight (1994) suggests the most basic crucial items are the date and country of issue for an item (75). Roberts (2007) provides significant background about philatelic materials and research, and indicates multiple metadata elements that will be helpful for researchers. He reiterates that dates are extremely useful, and are often identified on the materials themselves; when specific dates are not visible, a stamp itself may provide evidence of an approximate year based on when the stamp was issued (75). He notes that many of the postal markings also "indicate the time and place of origin, route, destination, and mode of transportation" (78), which will also be of interest to philatelic researchers. If any information is available about the original collector, dealer, or exhibitor of the stamp before it was acquired by a cultural heritage institution, this may also be of great interest to a researcher (81). Roberts also suggests that the finding aids for philatelic collections are more crucial places for description than for specific item records, and that controlled vocabulary subject terms are important in these descriptions (86).

Because the Scott Postage Stamp Catalogue is the leading United States authority on stamps, it can also suggest the metadata elements that primarily concern philatelic researchers. Each listing includes a unique Scott number, paper color, variety (e.g., perforation differences), basic information, denomination, color of the stamp, year of issue, value used/unused, any changes in the basic set information, and the total value of the set (Scott Publishing Co. 2014, 14A). The Scott Catalogue also describes a variety of additional components that researchers may be interested in, including the type of paper used, any watermarks, inks used, separation type, printing process used, luminescence, and gum condition (19A-25A).

One additional interesting source for deciding what metadata is important to researchers (aside from directly surveying them, of course) is a piece of software that was created to help philatelists catalog their own private collections. StampManage is available in United States and international versions, and it is largely based on the Scott Postage Stamp Catalogue in creating the full listing of stamps that may be available to a collector. It includes a wide variety of metadata elements for cataloging stamps, such as the Scott number, country of origin, date of issue, location of issue, type of stamp, denomination, condition, color, brief description, presence and type of perforations, category, plate block size, mint sheet size, paper type, presence and type of watermark, gum type, and so forth (Liberty Street Software 2016). As a product that is sold to stamp collectors, 
StampManage is likely to have a confident grasp of all the metadata that could possibly be important to its customers.

This literature review helps create a holistic view of the issues faced by cultural heritage institutions with digitized stamp collections. Although little progress has been made in the literature to describe how best to apply metadata to philatelic materials, there are ways that institutions can extrapolate guidelines from the literature that does exist.

\section{METHODOLOGY}

To explore my research questions, I interviewed (over email) representatives of several large institutions with digitized stamp collections. The information provided by these institutions sheds light on the current state of metadata and metadata schemas for philatelic collections. Note that there are other institutions with online collections of postage stamps that are not discussed in this paper (e.g., the Swedish Postal Museum, https://digitaltmuseum.se/owners/S-PM). Due to my own language limitations, this paper is limited to analysis of online collections that are described in English. Additional research into institutions with non-English displays would support greater analysis of how cultural heritage institutions are currently creating and providing philatelic metadata.

\section{RESULTS}

\section{Smithsonian National Postal Museum}

In the United States, the largest publicly accessible digital collection of philatelic materials is from the Smithsonian National Postal Museum. I discussed the metadata for this collection with Elizabeth Heydt, Collections Manager at the museum. Ms. Heydt stated that the stamps are primarily identified "by their country and their Scott number" (E. Heydt, pers. comm., October 5, 2016). For digital collections, the Smithsonian National Postal Museum uses a Gallery Systems database called The Museum System, which includes the Getty Art and Architecture Thesaurus as an embedded thesaurus. Ms. Heydt noted that aside from this embedded thesaurus, they "do not use any additional, formalized data standards such as the Dublin Core, MODS," or the like. Of note, The Museum System does allege compliance with "standards including SPECTRUM, CCO, CDWA, DACS, CHIN, LIDO, XMP, and other international standards" (Gallery Systems 2015, 4). The end user interface that pulls data from The Museum System is called Arago, which has "an internal structure that built on the Scott Catalogue system and some internal choices for grouping and classifying objects for the philatelic and the postal history collections." Users can search and browse the entire digital collection through Arago, but Ms. Heydt did note that Arago "is in stasis right now as we are in the planning stages for an updated version sometime in the near future."

Based on an example record (http://arago.si.edu/record_145471_img_1.html), the descriptive metadata currently available for end users include a title, Scott number, detailed description (including keywords), date of issue, medium, museum ID (a unique identifier), and place of origin. Digital images of the stamps are also included. A set of "breadcrumb" links at the top of the page also allow a user to browse each level of the digital collection, from an individual stamp record up to the entire museum collection as a whole. 


\section{Library and Archives Canada}

I discussed the Library and Archives Canada (LAC) online philatelic collection with James Bone, Archivist at the LAC. He explained that the philatelic collection has had a complicated history:

Our philatelic collection largely began with the dissolution of the National Postal Museum ... in 1989 and the subsequent division and transfer of its collection to the Canadian Postal Museum for artifacts/objects at the former Canadian Museum of Civilization (now the Canadian Museum of History) and to the Canadian Postal Archives at the former National Archives (which was merged with the National Library in the mid-2000s to create Library and Archives Canada). As a side note, both the Canadian Postal Museum and the Canadian Postal Archives are themselves now defunct - although LAC still acquires philatelic records and records related to philately and postal administration, these functions are no longer handled by a dedicated section but rather by archivists within our government records branch and our private records branch (the latter being me). (J. Bone, pers. comm., October 11, 2016)

Regarding the collection's metadata, Mr. Bone confirmed that the archival records at the LAC all conform to the RAD standard (discussed in the literature review above), and that philatelic materials are all given "at least a minimum level of useful file level or item level description for philatelic records based on Chapter 12 of RAD," the chapter that specifically discusses philatelic materials. Unfortunately, to his knowledge, the online database for these records does not use a common metadata standard such as OAI-PMH that enables "external metadata harvesting or querying," so the system is not searchable outside of the LAC website. Mr. Bone also pointed out that there are fields visible on the back end of the LAC online database that are not visible to end users, and the most notable of these omissions is the Scott number (the number assigned to every stamp by the Scott Catalogue). He wrote that it seemed "bizarre" to not have the Scott number visible, "as that's definitely an access point that I would expect philatelic researchers to use to narrow down a result set to the postage stamp issue of interest." However, it appears this invisibility was a decision consciously made by the LAC, based on Mr. Bone's review of an internal LAC standards document. Based on an example record (http://collectionscanada.gc.ca/pam_archives/index.php?fuseaction=genitem.displayltem\&lang= eng\&rec nbr $=2184475$ ) the following fields are available for end users to view: title, place of origin, denomination, date of issue, title of the collection of which it is a part, extent of item, language, access conditions, terms of use, MIKAN number (a unique identifier), ITEMLEV number (deprecated), and any additional relevant information such as previous exhibitions of the physical item.

\section{The Postal Museum}

The Postal Museum in London is set to open its physical doors in 2017, but much of the collection is already available for browsing and searching online. Stuart Aitken, Curator, Philately, explained to me that the online collection uses the General International Standard Archival Description, Second Edition, as the primary metadata schema, but the online collection also includes "non ISAD(G) fields for certain extra-specific data for our archive material, including philatelic material" (S. Aitken, pers. comm., December 1, 2016). Based on my own review of the ISAD(G) standards 
document (International Council on Archives 1999) and an example record from The Postal Museum's online collection

(http://catalogue.postalmuseum.org/collections/getrecord/GB813_P_150_06_02_011_01_001\#cu rrent), it appears nearly all the fields are based on the ISAD(G) standards. These fields include information such as date, level of description, extent of item, language, description, and conditions for access and reproduction. Only the field for "philatelic number" appears to be extra. There may be additional non-ISAD $(G)$ fields that are not included in the example record above, but are included in other records when the extra information is available and relevant.

Each digital record also allows end users to submit tags for help with identification and search. No tags were already submitted on the example record reviewed above, but this is likely because the online collection is still rather new. Of note, digital records are created at each archival level, from the broadest collection category down to the individual item (similar to the Smithsonian National Postal Museum collection). To provide an additional way to browse the collection, a sidebar in each digital record shows where it exists in the hierarchy of collections and provides links to each broader collection of which the current record is a part.

\section{The British Museum}

I reached out to the folks at The British Museum to discuss the application of metadata to their online records for postage stamps, but at the time of this writing I have not received any response. However, some information can be gleaned from examining the website. Unlike the other institutions reviewed in this paper, The British Museum's online collection includes a wide variety of objects. Postage stamps are therefore identified in the online collection by specifying "postagestamp" in the "Object type" field, which likely uses a controlled vocabulary. Based on an example record

(http://www.britishmuseum.org/research/collection_online/collection_object_details.aspx?objec

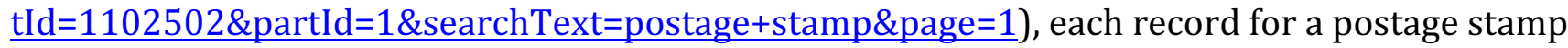
lists the museum number (a unique identifier), denomination, description, date issued, country of origin, materials, dimensions, acquisition name and date, department, and registration number (which appears to be the same as the museum number). Digital images of the stamps are occasionally included.

The collection website notes that The British Museum is "continuing every day to improve the information recorded in it [the digital collection] and changes are being fed through on a regular basis. In many cases it does not yet represent the best available knowledge about the objects" (Trustees of the British Museum 2016a, under "About these records"). Therefore, end users are encouraged to read the information in any given record with care, and to provide feedback if they have any additional information or corrections about an object.

The online collection also is offered in machine-readable format, via linked data and SPARQL, to encourage wider accessibility and use. The website advises,

The use of the W3C open data standard, RDF, allows the Museum's collection data to join and relate to a growing body of linked data published by other organisations around the world interested in promoting accessibility and collaboration. The data has also been organised using the CIDOC CRM (Conceptual Reference Model) crucial for harmonising 
with other cultural heritage data. The CIDOC CRM represents British Museum's data completely and, unlike other standards that fit data into a common set of data fields, all of the meaning contained in the Museum's source data is retained. (Trustees of the British Museum 2016b)

Each digital object has RDF and HTML resources, as well as a SPARQL endpoint with an HTML user interface.

\section{DISCUSSION}

The information from the four institutions above provides a starting point for examining best practices for philatelic metadata. In the following discussion, I will review the information in light of the research questions: important metadata elements, the standards that were implemented, and whether the standards that currently exist have been sufficient.

As explained in the literature review above, relevant metadata are crucial for enhancing end user research of digital records. This suggests that similarity of metadata across collections of the same type will improve users' ability to conduct their research. Unfortunately, there are only a few descriptive metadata fields used across all four of the institutions reviewed in this paper. These fields include a title (sometimes used very loosely), the date of issue, the place of issue, a description, and a unique identifier. These fields certainly seem to be the absolute minimum necessary for identifying (and searching for) a postage stamp, since they are among the fields discussed in the literature review as being important to philatelic researchers. Other fields that are included in some but not all of the above collections, such as stamp denomination and access conditions, are nonetheless quite relevant to online collections of postage stamps.

Interestingly, although the Scott Catalogue is recognized as a premier stamp catalogue, only one institution (the Smithsonian National Postal Museum) currently uses the Scott identification number as part of the standard philatelic metadata. As noted above, the Library and Archives Canada does include the Scott number in the behind-the-scenes metadata, but does it not display the Scott number to end users. The Postal Museum and The British Museum don't use the Scott number at all. It appears that only the Smithsonian believes the Scott number is useful to end users, either for search or identification purposes.

Of the four institutions, it appears that only The British Museum uses metadata standards that increase the accessibility of the online collection beyond its own website. The implementation of $\mathrm{RDF}$ for linked data creates an open collection that is machine-readable beyond the internal database used by the museum. The Smithsonian National Postal Museum, Library and Archives Canada, and The Postal Museum do not appear to use any similar metadata standard for data harvesting or transmission, which means that these collections can only be searched from within their respective websites.

The most important thing to note in reviewing the online collections for these four institutions is the fact that each institution uses different standards to apply metadata in a different way. Frankly, this is not a surprise. As discussed in the literature review above, although metadata standards exist for a variety of materials, philatelic materials are simply not considered. Only the Canadian Rules for Archival Description explicitly include information about philatelic materials; 
accordingly, the Library and Archives Canada utilizes these rules when creating its online records of postage stamps. No similar standard exists in the United States or internationally, leaving individual institutions with the task of deciding what generic metadata standard to use as a jumping off point, and then modifying it to meet local needs. As described above, the Smithsonian National Postal Museum uses the metadata schema that comes with their collection management software, and has created an end-user interface based off of internal metadata decisions. The Postal Museum based their metadata primarily off of ISAD(G), an international metadata standard with no specific suggestions for philatelic materials. I was unable to confirm the base metadata schema The British Museum employs, although it is clear they use RDF to make the collection's digital records more widely available. Each institution appears to be using a different base metadata standard, essentially requiring them to reinvent the wheel upon deciding to digitize philatelic materials. This is what happens when there is no single, unified standard available for the type of material being described.

\section{CONCLUSION}

As this paper has shown, metadata standards are sorely lacking when it comes to philatelic materials. Other kinds of materials have received special considerations because more and more institutions decided it would be important to digitize them, so various groups came together to create standards that provide some guidance. It is time for this to happen for philatelic materials as well. There aren't many cultural heritage institutions that currently manage digital collections of philatelic materials, so this is an opportunity for those who plan to digitize their collections to consider what has been done and what makes sense to pursue. It is clear that philatelic digitization is still nascent, but as with other kinds of materials, it is only likely that more and more institutions will attempt digitization projects. It is hoped that this paper can serve as a jumping off point for institutions to discuss the creation of international metadata standards specifically for philatelic materials.

\section{ACKNOWLEDGEMENTS}

Many thanks are owed to the people who took time out of their very busy lives to respond to the unrefined inquiries of an MLIS grad student: Stuart Aitken (Curator, Philately, The Postal Museum); James Bone (Archivist, Private Archives Branch, Library and Archives Canada); and Elizabeth Heydt (Collections Manager, Smithsonian National Postal Museum). Their expertise and responsiveness is immensely appreciated. 


\section{REFERENCES}

AAPE (American Association of Philatelic Exhibitors). 2016a. "AAPE - Join/Renew Your Membership." http://www.aape.org/join_the_aape.asp.

-----. 2016b. “Exhibits Online.” http://www.aape.org/join_the_aape.asp.

American Philatelic Society. 2016. "Stamp Catalogs: Your Guide to the Hobby." Accessed December 8. http://stamps.org/How-to-Read-a-Catalog.

Arms, Caroline R., and William Y. Arms. 2004. "Mixed Content and Mixed Metadata: Information Discovery in a Messy World." In Metadata in Practice, edited by Diane I. Hillman and Elaine L. Westbrooks, 223-37. Chicago, IL: ALA Editions.

Bade, David. 2007. "Structures, Standards, and the People Who Make Them Meaningful." Paper presented at the 2nd meeting of the Library of Congress Working Group on the Future of Bibliographic Control, Chicago, IL, May 9, 2007. https://www.loc.gov/bibliographicfuture/meetings/docs/bade-may9-2007.pdf.

Bade, David. 2008. "The Perfect Bibliographic Record: Platonic Ideal, Rhetorical Strategy or Nonsense?" Cataloging \& Classification Quarterly 46 (1): 109-33. https://doi.org/10.1080/01639370802183081.

Boggs, Winthrop S. 1955. The Foundations of Philately. Princeton, NJ: D. Van Nostrand Company.

Bruce, Thomas R., and Diane I. Hillmann. 2004. "The Continuum of Metadata Quality: Defining, Expressing, Exploiting." In Metadata in Practice, edited by Diane I. Hillman and Elaine L. Westbrooks, 238-56. Chicago, IL: ALA Editions.

Bureau of Canadian Archivists. 2008. Rules for Archival Description. Rev. ed. Ottawa, Canada: Canadian Council of Archives. http://www.cdncouncilarchives.ca/archdesrules.html.

CC:DA (American Library Association Committee on Cataloging: Description and Access). 2010. "Task Force on Metadata: Final Report." American Library Association. https://www.libraries.psu.edu/tas/jca/ccda/tf-meta6.html.

Chan, Lois M., and Marcia L. Zeng. 2006. "Metadata Interoperability and Standardization - A Study of Methodology Part I: Achieving Interoperability at the Schema Level." D-Lib Magazine 12 (6). https://doi.org/10.1045/june2006-chan.

Gallery Systems. 2015. “TMS: The Museum System.” http://go.gallerysystems.com/AboutTMS.html.

International Council on Archives. 1999. ISAD(G): General International Standard Archival Description. 2nd ed. Stockholm, Sweden: International Council on Archives. http://www.icacds.org.uk/eng/ISAD(G).pdf.

Liberty Street Software. 2016. "StampManage - The Best Way to Catalog Your Stamp Collection." http://www.libertystreet.com/Stamp-Collecting-Software.htm. 
Roberts, Peter J. 2007. "Philatelic Materials in Archival Collections: Their Appraisal, Preservation, and Description." The American Archivist 70 (1): 70-92. https://doi.org/10.17723/aarc.70.1.w3742751w5344275.

Scott Publishing Co. 2014. Scott 2015 Standard Postage Stamp Catalogue. Vol. 3, Countries of the World, G-I. Sidney, OH: Scott Publishing Co.

Society of American Archivists. 2013. Describing Archives: A Content Standard. 2nd ed. Chicago, IL: Society of American Archivists. http://files.archivists.org/pubs/DACS2E-2013_v0315.pdf.

Society of American Archivists. 2015. Encoded Archival Description Tag Library, Version EAD3. Chicago, IL: Society of American Archivists. http://www2.archivists.org/sites/all/files/TagLibrary-VersionEAD3.pdf.

Straight, David. 1994. "Adding Value to Stamp and Coin Collections." Library Journal 119 (10): 75 78. Accessed December 8, 2016.

http://libaccess.sjlibrary.org/login?url=http://search.ebscohost.com/login.aspx?direct=tr $\underline{\text { ue } \& \mathrm{db}=\mathrm{ulh} \& \mathrm{AN}=9406157617 \& \text { site }=\text { ehost-live } \& \text { scope }=\text { site }}$.

Trustees of the British Museum. 2016a. "About the Collection Database Online." Accessed December 8.

http://www.britishmuseum.org/research/collection_online/about_the_database.aspx.

-----. 2016b. "British Museum Semantic Web Collection Online.” Accessed December 8. http://collection.britishmuseum.org/. 